\title{
Time course changes of anti- and pro-apoptotic proteins in apigenin-induced genotoxicity
}

\author{
Fotini Papachristou ${ }^{1}$, Ekaterini Chatzaki ${ }^{2}$, Athanasios Petrou ${ }^{3}$, Ioanna Kougioumtzi ${ }^{3}$, Nikolaos Katsikogiannis ${ }^{3}$, \\ Alexandros Papalambros ${ }^{3}$, Grigorios Tripsianis ${ }^{4}$, Constantinos Simopoulos ${ }^{1,3}$ and Alexandra K Tsaroucha ${ }^{1,3^{*}}$
}

\begin{abstract}
Background: Apigenin (4',5,7-trihydroxyflavone, AP), an active component of many medicinal Chinese herbs, exhibits anticancer properties in vitro and in vivo. This study aims to investigate the genotoxic, cytostatic, and cytotoxic effects of AP and time course changes in the levels of anti- and pro-apoptotic proteins involved in the DNA damage response in HepG2 cells.

Methods: The genotoxic potential of AP was determined by sister chromatid exchanges (SCEs) and chromosomal aberrations (CAs) analysis. The levels of cytostaticity and cytotoxicity were evaluated by the proliferation rate and mitotic indices, respectively. MTT was used to study cytotoxicity, while the induction of apoptosis and the expression of apoptosis-related proteins were determined by ELISA.

Results: At concentrations greater than $10 \mu \mathrm{M}$, AP decreased cell survival in a dose- (48 h: 10 vs. $20 \mu \mathrm{M}, P<0.001$ and 20 vs. $50 \mu \mathrm{M}, P=0.005 ; 72$ h: 10 vs. $20 \mu \mathrm{M}, P<0.001$ and 20 vs. $50 \mu \mathrm{M}, P=0.001$ ) and time-dependent manner

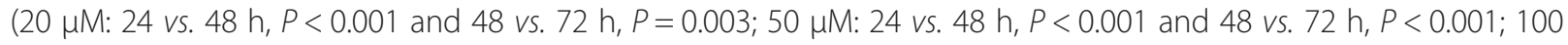
$\mu \mathrm{M}: 24$ vs. $48 \mathrm{~h}, P<0.001$ and 48 vs. $72 \mathrm{~h}, P<0.001)$. SCEs rates, cell proliferation, and mitotic divisions were also affected in a dose-dependent manner $(P<0.001)$. There was no change in the frequency of aberrant cells $(1 \mu \mathrm{M}$ AP: $P=0.554 ; 10 \mu \mathrm{M}$ AP: $P=0.337 ; 20 \mu \mathrm{M}$ AP: $P=0.239)$. Bcl-2 levels were reduced $3 \mathrm{~h}$ after AP administration $(P=0.003)$ and remained reduced throughout the $48 \mathrm{~h}$ observation period $(6 \mathrm{~h}, P=0.044 ; 12 \mathrm{~h}, P=0.001 ; 24 \mathrm{~h}, P=0.042 ; 48 \mathrm{~h}$, $P=0.012$ ). Bax and soluble Fas exhibited a transient upregulation $24 \mathrm{~h}$ after AP treatment. The Bax/Bcl-2 ratio was also increased at $12 \mathrm{~h}$ and remained increased throughout the $48 \mathrm{~h}$ observation period.

Conclusion: AP exhibited dose-dependent genotoxic potential in HepG2 cells. The protein levels of sFas, Bcl-2, and Bax were affected by AP to promote cell survival and cell death, respectively.
\end{abstract}

\section{Background}

Complementary and alternative medicine has potential to provide new drugs for cancer treatment [1-3]. Plantderived anticancer agents have already been used in the clinical practice, while many synthetic chemotherapeutics are analogs of natural products [3]. Apigenin (AP) is a bioflavone found in many Chinese medicinal herbs, such as Wedelia chinensis, Ixeris chinensis, Apium graveolens var. dulce, Scutellaria barbata, Andrographis

\footnotetext{
*Correspondence: atsarouc@med.duth.gr

${ }^{1}$ Cell Cultures Unit, Laboratory of Experimental Surgery and Surgical Research, Faculty of Medicine, Democritus University of Thrace, Dragana, Alexandroupolis, Greece

${ }^{3}$ Postgraduate Program in Hepatobiliary/Pancreatic Surgery, 2nd Department of Surgery, Faculty of Medicine, Democritus University of Thrace, Dragana, Alexandroupolis, Greece

Full list of author information is available at the end of the article
}

paniculata, Chrysanthemum morifolium, and Ginkgo biloba [1,4-10]. In vitro and in vivo studies have demonstrated that AP possesses antioxidant [11,12], antiinflammatory [13], and anticancer [14-16] properties, inhibiting tumor growth and inducing cell cycle arrest and apoptosis [17-20]. The anticancer properties of AP are associated with its pro-oxidant activity, with concentrations depending upon cell type [21-23]. AP promoted oxidative stress at $15 \mu \mathrm{M}$ in human cervical carcinoma HeLa cells [21], at $50 \mu \mathrm{M}$ in human promyelocytic leukemia HL-60 cells [22], and at $25 \mu \mathrm{M}$ in Chang liver cells [23].

AP induced apoptosis in the hepatic parenchyma [24-29], and exhibited antiproliferative and apoptotic properties in HepG2, Hep3B and PLC/PRF/5 human

\section{() Biomed Central}


liver cancer cell lines [25-28]. Its antiproliferative and apoptotic effects might be mediated through a p53dependent pathway by p53 accumulation, induction of p21 expression, and downregulation of CDK4 expression $[25,29]$. Generation of reactive oxygen species (ROS) might also play an important role in AP-induced apoptosis by transcriptionally downregulating catalase activity and increasing hydrogen peroxide levels [27,28]. Cell death induction has also been associated with $\mathrm{Bax} / \mathrm{Bcl}-2$ ratio changes, cytochrome c release, and Apaf- 1 induction, leading to caspase activation and PARP-cleavage in leukemia, prostate carcinoma, lung cancer, and cervical carcinoma cells [19,30-33].

Although the properties of AP against various prooxidant and clastogenic agents have been studied [11,34-36], there is little information on the genotoxic potential of this particular flavonoid. AP was highly clastogenic in Chinese hamster V79 cells and induced micronuclei formation in human peripheral lymphocytes in a dose-dependent manner $[37,38]$. Other reports mentioned that AP could intercalate into both calf thymus DNA and RNA [39,40]. The generation of DNA single-strand (SSBs) and double-strand breaks (DSBs) by DNA-crosslinking agents [41,42], could lead to sister chromatid exchanges (SCEs) or chromosomal aberrations (CAs) [43]. An in vivo and in vitro study demonstrated that AP can remodel chromatin by inhibiting class I histone deacetylases. This affects regulation, expression, and activation of various DNA damage response genes, which results in cell cycle arrest, and apoptosis. These affected genes include $A T M$ and $A T R$, which participate in DSBs repair via homologous recombination $[44,45]$.

The SCEs assay is a sensitive, simple, and rapid method to detect DNA damage and repair at low concentrations of potential genotoxic or anti-genotoxic agents [43,46-49]. SCEs represent a useful tool in monitoring and improving chemotherapeutic strategies in vitro and in vivo [48,50-54]. The efficacy of potential antitumor agents in inducing SCEs formation in vitro and in vivo correlates positively with the in vivo tumor's response to these agents [55,56]. CAs analysis is another genotoxic endpoint $[43,46]$. A high frequency of CAs can lead to cell death, and it has been associated with increased overall cancer risk $[43,46,57,58]$.

AP's ability to intercalate into DNA, remodel chromatin, and upregulate p53 and p21 proteins [25,39,40,44,59-61] directed us to study the genotoxic potential of this flavonoid in HepG2 cells. We also investigated the proliferation rate index (PRI) and the mitotic index (MI), markers of the cytostatic and cytotoxic properties of chemical and physical agents, respectively [49]. The time course changes in the levels of anti- and pro-apoptotic proteins involved in the DNA damage response were also investigated.

\section{Methods}

\section{Chemicals}

Apigenin (4',5,7-trihydroxyflavone) was purchased from Calbiochem (San Diego, CA, USA). Bovine serum albumin, Bradford reagent, dimethyl sulfoxide (DMSO), and 3-(4,5dimethylthiazol-2-yl)-2,5-diphenyl tetrazolium bromide (MTT) were purchased from Sigma (St. Louis, MO, USA). 5-bromodeoxyuridine and bisbenzimide H33258 were purchased from AppliChem (Darmstadt, Germany). High glucose Dulbecco's modified Eagle's medium (DMEM), trypsin-EDTA solution, colcemid, fetal bovine serum (FBS), and penicillin/streptomycin solution (10,000:10,000) were purchased from GIBCO (Carlsbad, CA, USA). Cell death detection ELISA ${ }^{\text {Plus }}$ kit was purchased from Roche (Mannheim, Germany). Human sFas and human sFas ligand ELISA kits were purchased from $R \& D$ systems (Minneapolis, MN, USA). Human Bax ELISA kit was purchased from Assay Designs, Inc. (Ann Arbor, MI, USA) and human Bcl-2 ELISA kit was purchased from Bender Medsystems (Vienna, Austria).

\section{Cell cultures}

HepG2 cells were maintained in DMEM supplemented with $10 \% \mathrm{FBS}$ and $1 \%$ penicillin/streptomycin solution, in a $37^{\circ} \mathrm{C}$ humidified incubator under an atmosphere of $5 \% \mathrm{CO}_{2}$. On attaining 75-80\% confluency the cells were subcultured by trypsinization and then seeded in appropriate cell numbers depending on the type of the experiments. All experiments took place $24 \mathrm{~h}$ after seeding.

\section{Cytotoxicity assay}

The cytotoxic potential of AP was evaluated at 24, 48, and $72 \mathrm{~h}$ by the MTT method. HepG2 cells were seeded in $96-$ well plates at a density of $10^{4}$ cells per well in $100 \mu \mathrm{L}$ of complete culture medium. Cells were incubated with 0.1 , $1,5,10,20,50$, and $100 \mu \mathrm{M}$ of AP or $0.1 \%$ DMSO (vehicle control). AP stock solution was prepared in DMSO and diluted in complete culture medium to the desired concentrations $(0.1,1,5,10,20,50$, and $100 \mu \mathrm{M})$. At each time point, eight replicate cultures for each concentration were studied in three independent experiments. At the end of the specified incubation period $(24,48$, and $72 \mathrm{~h})$, the medium was discarded and each well received $200 \mu \mathrm{L}$ of fresh medium containing $20 \mu \mathrm{L}$ of MTT solution $(5 \mathrm{mg} / \mathrm{ml}$ in phosphate buffered saline) for $4 \mathrm{~h}$. MTT crystals were dissolved by adding $100 \mu \mathrm{L} 0.04 \mathrm{M} \mathrm{HCL}$ /isopropanol, for fifteen minutes at $37^{\circ} \mathrm{C}$. Absorbance was determined at 570 $\mathrm{nm}$ by an ExpertPlus microplate reader (ASYS Hitech $\mathrm{GmbH}$, Austria). Absorbance was normalized to vehicletreated control cultures (equivalent to $100 \%$ cell viability).

\section{SCEs and CAs analysis}

For SCEs and CAs determination, $2 \times 10^{5}$ cells were treated with $1,10,20$, and $50 \mu \mathrm{M}$ of $\mathrm{AP}$ and $5 \mu \mathrm{g} / \mathrm{mL}$ of 
5-bromodeoxyuridine for $72 \mathrm{~h}$. Colcemid was added to all cultures $24 \mathrm{~h}$ before metaphase harvesting. At the end of the incubation period, the cells were scraped and centrifuged (Z300, Hermle Labortechnik $\mathrm{GmbH}$, Germany) at $200 \times g$ for $10 \mathrm{~min}$. Pelleted cells were then treated with $5 \mathrm{~mL}$ of hypotonic $\mathrm{KCl}$ solution $(0.075 \mathrm{M})$, at $37^{\circ} \mathrm{C}$ for $25 \mathrm{~min}$. Fixative solution (3:1, methanol:acetic acid) was added to the cell suspension and was followed by another centrifugation at $200 \times g$ for $10 \mathrm{~min}$. The pellet was washed three times in fixative solution and stored at $-20^{\circ} \mathrm{C}$ until further assayed. All treatments were examined in three independent experiments.

\section{Fluorescence plus Giemsa}

SCEs were visualized by a modified fluorescence plus Giemsa (FPG) technique [62]. Metaphase spreads were incubated in bisbenzimide $\mathrm{H} 33258$ solution $(0.1 \mathrm{mg} / \mathrm{mL})$ for $20 \mathrm{~min}$ at room temperature. A few drops of McIlivaine's buffer ( $\mathrm{pH} 8 ; 0.1 \mathrm{M}$ citric acid and $0.2 \mathrm{M}$ disodium phosphate) were applied to each slide and overlaid with a coverslip. After that, the slides were exposed to UV light for $90 \mathrm{~min}$ and stained with $7 \%$ Giemsa solution in Gurr buffer (pH 6.8).

Since the number of chromosomes in HepG2 cells varies from 50 to 60 (modal number: 55), the SCEs/ chromosome rate was estimated. SCEs were evaluated in more than 60 well-spread second-division metaphases for each treatment. CAs were evaluated in 300 first division metaphases for each treatment. The criteria to classify different types of aberrations were in accordance with the recommendations of IPCS guidelines [43]. CAs were classified as chromatid gaps (chtg), chromatid breaks (chtb), chromosome gaps (chrg), chromosome breaks (chrb), ring (r), and dicentric chromosomes (d). Gaps were not included in the determination of total aberrant cells per treatment. Scoring was performed in a blind fashion.

\section{PRI and $\mathrm{MI}$ assessment}

For PRI and MI determinations, more than 450 cells and 4,500 nuclei were scored for each treatment, respectively. The proportion of cells in the first, second, third, or subsequent mitotic division was evaluated to determine the PRI. PRI was established according to the following formula:

$$
\mathrm{PRI}=\left(\Sigma \mathrm{M}_{1}+2 * \Sigma \mathrm{M}_{2}+3 * \Sigma \mathrm{M}_{3+}\right) / \mathrm{N}
$$

where $\Sigma M_{1}$ is the sum of cells in the first mitotic division, $\Sigma M_{2}$ in the second and $\Sigma M_{3+}$ in the third or subsequent mitotic divisions, while $\mathrm{N}$ is the total number of cells scored [63]. MI was expressed as the number of cells at metaphase per 1,000 analyzed nuclei (\%o).

\section{Assessment of apoptosis}

As an index of apoptosis, cytoplasmic histone-associated DNA fragments were photometrically determined by the Cell Death Detection ELISA ${ }^{\text {Plus }}$ kit according to the manufacturer's instructions. Ten thousand cells per well were seeded in 96-well plates and treated with AP $(20 \mu \mathrm{M})$ for $24 \mathrm{~h}$ (six replicate cultures). Cells were lysed and centrifuged at $130 \times g$. Supernatants were transferred into a streptavidin-coated microplate and simultaneously incubated with a monoclonal mouse biotinylated anti-histone antibody (clone H11-4) and a monoclonal mouse peroxidase-conjugated anti-DNA antibody (clone MCA-33) at room temperature for $2 \mathrm{~h}$. DNA-histone complex was used as a positive control. Absorbance was determined at $405 \mathrm{~nm}$ by an ExpertPlus microplate reader. Background values were subtracted from the measurements.

\section{Determination of sFas, $\mathrm{mFasL}, \mathrm{sFasL}, \mathrm{Bcl}-2$, and Bax protein levels}

Protein levels of soluble Fas (sFas), membrane-bound FasLigand (mFasL), soluble Fas-Ligand (sFasL), Bcl-2, and


Figure 1 The effect of apigenin on cell viability and induction of apoptosis. A. The cytotoxic and antiproliferative effect of apigenin in HepG2 cells. B. The apoptotic potential of apigenin $(20 \mu \mathrm{M})$ after $24 \mathrm{~h}$ of treatment. The star $\left(^{*}\right)$ indicates statistical significance compared with control cultures. 
Table 1 The effect of apigenin on the frequency of chromosomal aberrations

\begin{tabular}{|c|c|c|c|c|c|c|c|c|}
\hline & \multirow{2}{*}{$\begin{array}{l}\text { No. cells } \\
\text { scored }\end{array}$} & \multirow{2}{*}{$\begin{array}{c}\% \text { of aberrant cells } \\
\qquad( \pm \text { SD })\end{array}$} & \multicolumn{6}{|c|}{ Chromosomal aberrations/cell } \\
\hline & & & chtg & chtb/f & chrg & chrb/f & $\mathbf{r}$ & d \\
\hline Untreated control & 300 & $55.8 \pm 14.27$ & $0.16 \pm 0.03$ & $0.51 \pm 0.15$ & $0.10 \pm 0.07$ & $0.20 \pm 0.15$ & $0.035 \pm 0.03$ & $0.010 \pm 0.01$ \\
\hline Vehicle control & 300 & $60.5 \pm 5.05$ & $0.15 \pm 0.09$ & $0.63 \pm 0.19$ & $0.05 \pm 0.03$ & $0.32 \pm 0.06$ & $0.003 \pm 0.01$ & $0.003 \pm 0.01$ \\
\hline AP $(1 \mu \mathrm{M})$ & 303 & $56.2 \pm 12.57$ & $0.08 \pm 0.01$ & $0.49 \pm 0.09$ & $0.05 \pm 0.03$ & $0.27 \pm 0.18$ & $0.013 \pm 0.02$ & $0.003 \pm 0.01$ \\
\hline AP $(10 \mu \mathrm{M})$ & 300 & $68.2 \pm 13.88$ & $0.13 \pm 0.07$ & $0.63 \pm 0.12$ & $0.06 \pm 0.02$ & $0.33 \pm 0.16$ & $0.022 \pm 0.03$ & $0.000 \pm 0.00$ \\
\hline AP $(20 \mu M)$ & 300 & $66.0 \pm 6.60$ & $0.16 \pm 0.06$ & $0.56 \pm 0.05$ & $0.07 \pm 0.03$ & $0.41 \pm 0.03$ & $0.024 \pm 0.02$ & $0.010 \pm 0.01$ \\
\hline
\end{tabular}

chtg: chromatid gap; chtb: chromatid break; f: fragment; chrg: chromosome gap; chrb: chromosome break; r: ring; d: dicentric.

Bax were determined by ELISA according to the manufacturers' instructions. HepG2 cells were treated with $20 \mu \mathrm{M}$ of AP for 1, 3, 6, 12, 24, and 48 h. Soluble Fas, sFasL, and mFasL protein levels were evaluated in the supernatant or cell lysate of $1 \times 10^{6}$ cells $/ \mathrm{mL}$. Bcl- 2 and Bax protein levels were determined in $5 \times 10^{5}$ cells $/ \mathrm{mL}$ and 62,500 cells $/ \mathrm{mL}$ cell lysates, respectively. Bradford protein assay was used for total protein determination. Protein levels were interpolated from the corresponding standard reference calibration curves. Three independent experiments took place at all time points.

\section{Statistical analysis}

Data were expressed as mean \pm standard deviation (SD). SCEs and CAs values were logarithmically transformed before further analysis because data were not normally distributed. Statistical analysis was performed by Student's $t$-test for individual comparisons between control and apigenin-treated cultures. Multiple comparisons among various AP treatments were carried out by oneway ANOVA followed by Bonferroni's post hoc test. Linear regression analysis was used to determine doseresponse relationships. Pearson's correlation coefficient was also determined. All statistical analyses were performed by SPPS version 16 (IBM, USA). All tests were two-tailed and $P$ values less than 0.05 were considered statistically significant. For Student's $t$-test, significance levels were adjusted to 0.01 to reduce the overall Type I error.

\section{Results and discussion}

AP concentrations ranging from 10 to $50 \mu \mathrm{M}$ at 48 and $72 \mathrm{~h}$ showed a dose-response relationship of cell survival (48 h: 10 vs. $20 \mu \mathrm{M}, P<0.001$ and $20 \nu s .50 \mu \mathrm{M}$, $P=0.005 ; 72$ h: 10 vs. $20 \mu \mathrm{M}, P<0.001$ and 20 vs. $50 \mu \mathrm{M}$, $P=0.001$ ), while AP concentrations ranging from 20$100 \mu \mathrm{M}$ showed a time-dependent decrease $(20 \mu \mathrm{M}: 24$ vs. $48 \mathrm{~h}, P<0.001$ and 48 vs. $72 \mathrm{~h}, P=0.003 ; 50 \mu \mathrm{M}: 24$ vs. $48 \mathrm{~h}, P<0.001$ and 48 vs. $72 \mathrm{~h}, P<0.001 ; 100 \mu \mathrm{M}$ : 24 vs. $48 \mathrm{~h}, P<0.001$ and 48 vs. $72 \mathrm{~h}, P<0.001)$ (48 h: $\mathrm{IC}_{50}=34.58 \mu \mathrm{M} ; 72 \mathrm{~h}: \mathrm{IC}_{50}=18.80 \mu \mathrm{M}$ ) (Figure 1A). Similar results were reported by Chiang et al. [25] and Choi et al. [27], who studied the antiproliferative effect of AP in HepG2 cells. In agreement with Khan et al. [26], AP induced apoptosis at $24 \mathrm{~h}$, eliciting an 11-fold increase in cytoplasmic histone-associated DNA fragments $(P<0.001)$ (Figure $1 \mathrm{~B})$.

AP $(100 \mu \mathrm{M})$ induced DNA damage in Chinese hamster V79 cells and increased the frequency of micronuclei and CAs (concentrations higher than $37 \mu \mathrm{M}$ ) in human peripheral lymphocytes $[34,36-38,64,65]$. In our study, we observed no effect on the frequency of aberrant cells (Table 1) but we noticed an increase in the frequency of SCEs at much lower concentrations (10 and $20 \mu \mathrm{M})$. However, $50 \mu \mathrm{M}$ of AP was highly cytotoxic, making SCEs evaluation impossible (Table 2). This could be attributed to the high sensitivity of the SCEs method for detecting DNA damage and repair at doses that have little or no effect on CAs frequency $[46-49,66]$. Moreover, the independent mechanisms leading to SCEs and CAs formation [46,67-69] and the use of different cell systems could account for the differences. HepG2 cells have a polymorphic genetic profile with a variety of structural and numerical chromosomal abnormalities [70-72]. Sixty-seven breakpoints were identified in liver cancer cell lines including HepG2 cells [72]. Zimonjic et al. [71] performed comparative genomic hybridization analysis in 18 liver cancer cell lines and reported that regions exhibiting gain or loss, ranged from whole chromosome arms to a medium band of a 400-band

Table 2 The genotoxic, cytostatic, and cytotoxic potential of apigenin

\begin{tabular}{cccc}
\hline Agents & $\begin{array}{c}\text { SCEs/chromosome } \pm \text { SD } \\
\text { (range of values) }\end{array}$ & PRI & MI (\%o) \\
\hline $\begin{array}{c}\text { Untreated } \\
\text { control }\end{array}$ & $0.17 \pm 0.08(0.04-0.42)$ & $2.64 \pm 0.03$ & $76.3 \pm 9.50$ \\
Vehicle control & $0.15 \pm 0.08(0.03-0.33)$ & $2.65 \pm 0.06$ & $87.3 \pm 20.20$ \\
AP $(1 \mu \mathrm{M})$ & $0.15 \pm 0.09(0.04-0.42)$ & $2.61 \pm 0.10$ & $63.0 \pm 19.52$ \\
AP $(10 \mu \mathrm{M})$ & $0.22 \pm 0.14^{*, a}(0.03-0.69)$ & $2.52 \pm 0.13$ & $57.0 \pm 22.84$ \\
AP $(20 \mu \mathrm{M})$ & $0.26 \pm 0.12^{*, b, c}(0.07-0.64)$ & $2.09 \pm 0.12^{*, d}$ & $32.7 \pm 7.96^{*}$ \\
AP $(50 \mu \mathrm{M})$ & $\mathrm{ND}$ & $\mathrm{ND}$ & $9.3 \pm 7.57^{*, \mathrm{e}}$ \\
\hline
\end{tabular}

${ }^{*} P \leq 0.01$ vs. vehicle control; ${ }^{\mathrm{a}} P<0.01$ vs. $1 \mu \mathrm{M} ;{ }^{\mathrm{b}} P<0.001$ vs. $1 \mu \mathrm{M} ;{ }^{\mathrm{c}} P<0.05$ vs. $10 \mu \mathrm{M} ;{ }^{\mathrm{d}} P \leq 0.001$ vs. 1 and $10 \mu \mathrm{M} ;{ }^{\mathrm{e}} P<0.01$ vs. 1,10 and $20 \mu \mathrm{M}$. ND: values could not be determined. 
Table 3 The effect of apigenin on cell cycle kinetics

\begin{tabular}{cccc}
\hline \multirow{2}{*}{ Agents } & \multicolumn{3}{c}{$\begin{array}{c}\text { Mean }\left( \pm \text { SD) number of cells in the } \mathbf{1}^{\text {st }}, \mathbf{2}^{\text {nd }}, \mathbf{3}^{\text {rd }},\right. \\
\text { and subsequent mitotic divisions }\end{array}$} \\
\cline { 2 - 4 } & $\mathbf{1}^{\text {st }}$ & $\mathbf{2}^{\text {nd }}$ & $\mathbf{3}^{\text {rd+ }}$ \\
\hline Untreated control & $4.3 \pm 1.15$ & $39.0 \pm 9.54$ & $89.7 \pm 20.55$ \\
Vehicle control & $5.0 \pm 2.65$ & $42.0 \pm 10.44$ & $103.0 \pm 9.17$ \\
AP $(1 \mu M)$ & $4.0 \pm 2.65$ & $50.0 \pm 9.54$ & $97.3 \pm 14.05$ \\
AP $(10 \mu M)$ & $7.4 \pm 3.65$ & $57.2 \pm 16.57$ & $85.2 \pm 17.34$ \\
AP $(20 \mu M)$ & $20.2 \pm 5.40^{*, a, b}$ & $89.4 \pm 20.38^{*, c}$ & $34.2 \pm 16.45^{*, a, d}$ \\
\hline
\end{tabular}

${ }^{*} P \leq 0.01$ vs. vehicle control; ${ }^{\mathrm{a}} P<0.01$ vs. $1 \mu \mathrm{M}$; ${ }^{\mathrm{b}} P<0.05$ vs. $10 \mu \mathrm{M} ;{ }^{\mathrm{c}} P<0.05$ vs. 1 and $10 \mu \mathrm{M} ;{ }^{d} P<0.01$ vs. $10 \mu \mathrm{M}$.

ideogram. These previous findings could justify the high frequency of aberrant cells found in the control groups in the present study.

Linear regression analysis revealed a dose-response relationship between AP and SCEs frequencies, cell proliferation, and mitotic divisions $\left(R=0.798, R^{2}=0.636\right.$, $P<0.001 ; \mathrm{R}=-0.883, \mathrm{R}^{2}=0.781, P<0.001 ; \mathrm{R}=-0.820$, $\mathrm{R}^{2}=0.672, P<0.001$, respectively). AP concentration was positively correlated with the first and second mitotic division metaphases $\left(\mathrm{R}=0.837, \mathrm{R}^{2}=0.700, P<0.001\right.$; $\mathrm{R}=0.768, \mathrm{R}^{2}=0.589, P<0.001$, respectively), while the third and subsequent mitotic division metaphases were negatively correlated $\left(\mathrm{R}=-0.867, \mathrm{R}^{2}=0.751, P<0.001\right)$ with AP (Table 3). The flavonoid's genotoxic potential was correlated with increased cytostaticity (SCEs $v s$. PRI: $\left.\mathrm{R}=-0.582, \mathrm{R}^{2}=0.339, P=0.018\right)$ and cytotoxicity (SCEs vs. MI: $\mathrm{R}=-0.573, \mathrm{R}^{2}=0.329, P=0.032$ ).

DSBs are repaired by homologous recombination, in which SCEs play an important role [73-75]. Iijima et al. [76] reported that NBS1, a protein involved in cellular responses to DSBs [77], regulated Bax activation in DNA damage-induced apoptosis. Furthermore, pro-apoptotic $B A X$ could comprise a p53 downstream target gene

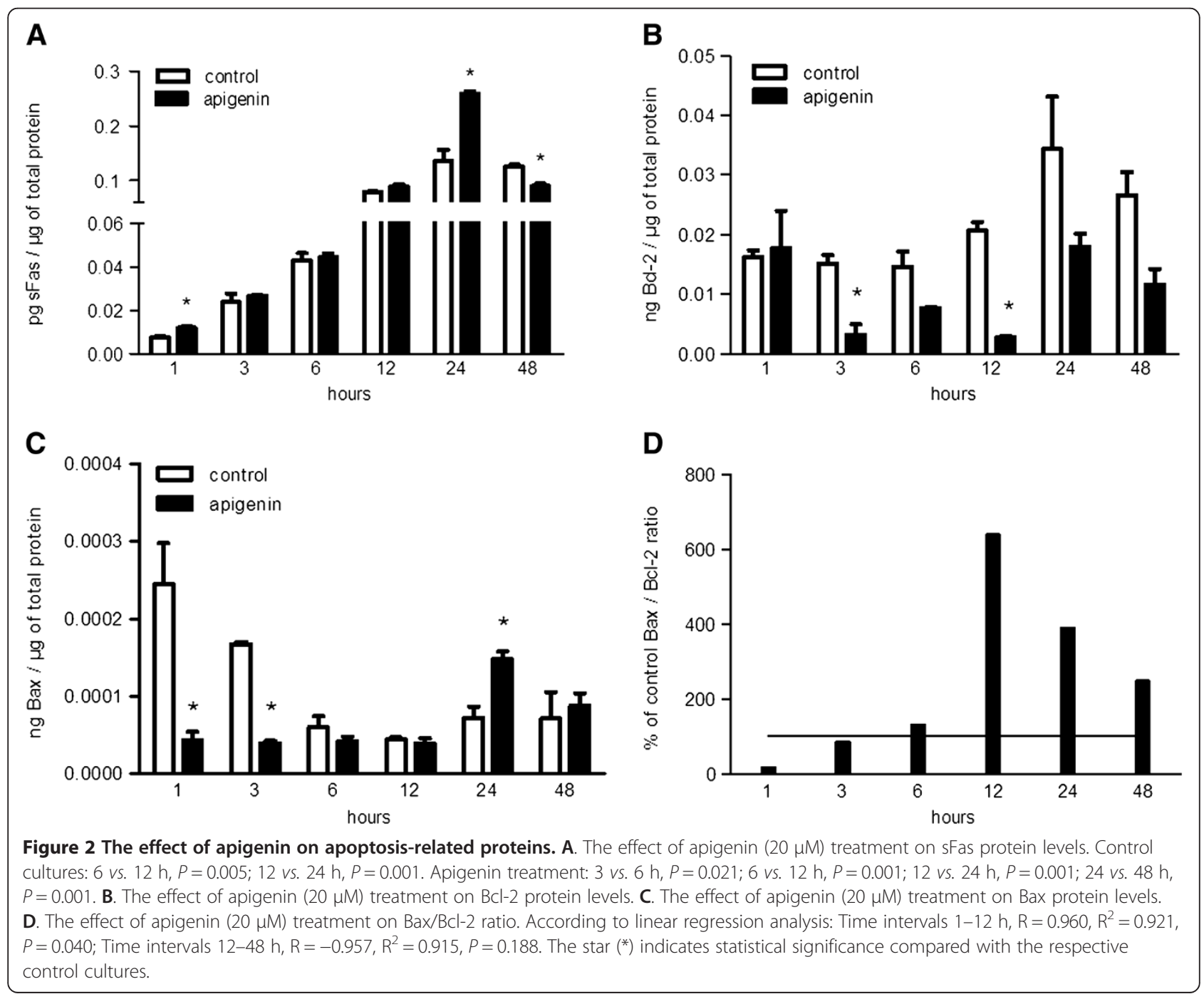


through the direct binding of p53 to cofactors ASPP1 and ASPP2 $[78,79]$. Bcl-2 could protect cells against cell death induced by ionizing radiation, alkylating agents, and various chemotherapeutic drugs [80-83]. Formation of DSBs by severe DNA damage triggered Bcl-2 decline and activated caspase-9 and caspase-3 [84]. In our study, AP treatment affected both $\mathrm{Bcl}-2$ and Bax protein levels. $\mathrm{Bcl}-2$ expression was downregulated at 3-48 h (Figure 2B). Bax levels were significantly lower in apigenin-treated cells at 1 and $3 \mathrm{~h}(P=0.003$ and $P<0.001$, respectively $)$ (Figure $2 \mathrm{C}$ ). At $24 \mathrm{~h}, \mathrm{Bax}$ expression was significantly upregulated compared with the corresponding vehicletreated cultures $(P=0.005)$ and the respective $12 \mathrm{~h}$ of treatment $(P=0.001)$. Bax's upregulation was transient and significantly reduced to the corresponding control cultures levels after $48 \mathrm{~h}$. The Bax/Bcl-2 ratio, which is indicative of the mitochondrial induced apoptotic potential, exhibited a noticeable increase from $12-48 \mathrm{~h}$ of treatment (Figure 2D). Similar changes in the Bax/Bcl-2 ratio were observed in human lung A549 cancer cells and human prostate carcinoma DU145 cells $[32,33]$.

Genotoxic agents could lead to cell death through the Fas/FasL mediated apoptotic pathway $[85,86]$. In the present study, mFasL and sFasL were undetectable at all time points in all cultures. Nevertheless, sFas increased in a time-dependent manner in untreated and treated cultures (Control cultures: 6 vs. $12 \mathrm{~h}, P=0.005 ; 12$ vs. $24 \mathrm{~h}, P=0.001$. Apigenin treatment: 3 vs. $6 \mathrm{~h}, P=0.021$; 6 vs. $12 \mathrm{~h}, P=0.001 ; 12$ vs. $24 \mathrm{~h}, P=0.001 ; 24$ vs. $48 \mathrm{~h}$, $P=0.001$ ) (Figure 2A). AP increased sFas levels at 1 and $24 \mathrm{~h}$, compared with the corresponding control cultures $(P=0.002$ and $P=0.001$, respectively). Upregulation of sFas at $24 \mathrm{~h}$, was transient and significantly reduced at $48 \mathrm{~h}$, compared with the respective $24 \mathrm{~h}$ treatment $(P=0.001)$ and the corresponding control cultures $(P=$ 0.001). There are no previous reports on the effect of AP on alternatively spliced $F A S$. Fas-mediated signaling is not limited to inducing cell death, and its expression in various cell types does not always correlate with susceptibility to the Fas-mediated apoptotic pathway [86,87]. Alternatively, spliced $F A S$ variants, which encode soluble forms of the receptor, could inhibit apoptosis [88-90]. Because of the sharp Bcl-2 downregulation at $12 \mathrm{~h}, \mathrm{sFas}$ upregulation might represent a rescuing mechanism as a means to prevail over cell death signals. Filippov et al. [91] reported that cells in response to exogenous stress, such as the effect of a genotoxic agent, regulated the expression of specific splicing factors, altering the splicing profile of target genes such as CD44 and FAS. Since ROS induce alternative splicing, it is possible that free oxygen radical generation by AP could justify the induction of sFas expression [27,92,93]. AP's intercalation into DNA/RNA might have also contributed to these changes in the expression of $F A S$.

\section{Conclusion}

AP exhibited dose-dependent genotoxic potential that led to changes in sFas, Bcl-2, and Bax protein levels in HepG2 cells.

\section{Abbreviations}

AP: Apigenin; CAs: Chromosomal aberrations; chrb: Chromosome break chrg, chromosome gap; chtb: Chromatid break; chtg: Chromatid gap; d: Dicentric chromosome; DMEM: Dulbecco's modified Eagle's medium; DMSO: Dimethyl sulfoxide; DSBs: Double-strand breaks; f: Fragment; FBS: Fetal bovine serum; mFas: Membrane-bound Fas; mFasL: Membrane-bound Fas-Ligand; MI: Mitotic index; MTT: 3-(4,5-dimethylthiazol-2-yl)-2,5-diphenyl tetrazolium bromide; PRI: Proliferation rate index; r: Ring chromosome; ROS: Reactive oxygen species; SCEs: Sister chromatid exchanges; SD: Standard deviation; sFas: Soluble Fas; SFasL: Soluble Fas-Ligand; SSBs: Single-strand breaks.

\section{Competing interests}

The authors declare that they have no competing interests.

\section{Authors' contributions}

CS, EC and AKT designed and supervised the study. FP wrote the manuscript and conducted the experiments. AtP, IK, NK, and AIP assisted experimentally and drafted parts of the manuscript. GT and FP performed the statistical analysis. All authors read and approved the final version of the manuscript.

\section{Acknowledgements}

The authors would like to thank Assoc. Prof. G. Kolios, Department of Pharmacology, Medical School, Democritus University of Thrace, Alexandroupolis, Greece for kindly providing the HepG2 cell line and Katherine Bahk for language editing

\section{Author details}

${ }^{1}$ Cell Cultures Unit, Laboratory of Experimental Surgery and Surgical Research, Faculty of Medicine, Democritus University of Thrace, Dragana, Alexandroupolis, Greece. ${ }^{2}$ Laboratory of Pharmacology, Faculty of Medicine, Democritus University of Thrace, Dragana, Alexandroupolis, Greece.

${ }^{3}$ Postgraduate Program in Hepatobiliary/Pancreatic Surgery, 2nd Department of Surgery, Faculty of Medicine, Democritus University of Thrace, Dragana, Alexandroupolis, Greece. ${ }^{4}$ Laboratory of Medical Statistics, Faculty of

Medicine, Democritus University of Thrace, Dragana, Alexandroupolis, Greece.

Received: 19 June 2012 Accepted: 30 April 2013

Published: 4 May 2013

\section{References}

1. Wang Z, Wang N, Chen J, Shen J: Emerging glycolysis targeting and drug discovery from Chinese medicine in cancer therapy. Evid Based Complement Alternat Med 2012, 2012:873175.

2. Carmady B, Smith CA: Use of Chinese medicine by cancer patients: a review of surveys. Chin Med 2011, 6:22.

3. Cragg GM, Newman DJ: Plants as a source of anti-cancer agents. J Ethnopharmacol 2005, 100:72-79.

4. Kim DI, Lee TK, Lim IS, Kim H, Lee YC, Kim CH: Regulation of IGF-I production and proliferation of human leiomyomal smooth muscle cells by Scutellaria barbata D. Don in vitro: isolation of flavonoids of apigenin and luteolin as acting compounds. Toxicol Appl Pharmacol 2005, 205:213-224.

5. Cao Y, Chu Q, Fang Y, Ye J: Analysis of flavonoids in Ginkgo biloba L. and its phytopharmaceuticals by capillary electrophoresis with electrochemical detection. Anal Bioanal Chem 2002, 374:294-299.

6. Zheng QS, Sun XL, Xu B, Li G, Song M: Mechanisms of apigenin7-glucoside as a hepatoprotective agent. Biomed Environ Sci 2005, 18:65-70.

7. Tsai CH, Lin FM, Yang YC, Lee MT, Cha TL, Wu GJ, Hsieh SC, Hsiao PW: Herbal extract of Wedelia chinensis attenuates androgen receptor activity and orthotopic growth of prostate cancer in nude mice. Clin Cancer Res 2009, 15:5435-5444.

8. Chao WW, Lin BF: Isolation and identification of bioactive compounds in Andrographis paniculata (Chuanxinlian). Chin Med 2010, 5:17. 
9. Lu XY, Sun DL, Chen ZJ, Chen T, Li LP, Xu ZH, Jiang HD, Zeng S: Relative contribution of small and large intestine to deglycosylation and absorption of flavonoids from Chrysanthemun morifolium extract. J Agric Food Chem 2010, 58:10661-10667.

10. Chen Z, Kong S, Song F, Li L, Jiang H: Pharmacokinetic study of luteolin, apigenin, chrysoeriol and diosmetin after oral administration of Flos Chrysanthemi extract in rats. Fitoterapia 2012, 83:1616-1622.

11. Kuo ML, Lee KC, Lin JK: Genotoxicities of nitropyrenes and their modulation by apigenin, tannic acid, ellagic acid and indole-3 -carbinol in the Salmonella and CHO systems. Mutat Res 1992, 270:87-95.

12. Myhrstad MC, Carlsen H, Nordstrom O, Blomhoff R, Moskaug JO: Flavonoids increase the intracellular glutathione level by transactivation of the gamma-glutamylcysteine synthetase catalytical subunit promoter. Free Radic Biol Med 2002, 32:386-393.

13. Liang YC, Huang YT, Tsai SH, Lin-Shiau SY, Chen CF, Lin JK: Suppression of inducible cyclooxygenase and inducible nitric oxide synthase by apigenin and related flavonoids in mouse macrophages. Carcinogenesis 1999, 20:1945-1952

14. Wei $H$, Tye L, Bresnick E, Birt DF: Inhibitory effect of apigenin, a plant flavonoid, on epidermal ornithine decarboxylase and skin tumor promotion in mice. Cancer Res 1990, 50:499-502.

15. Birt DF, Mitchell D, Gold B, Pour P, Pinch HC: Inhibition of ultraviolet light induced skin carcinogenesis in SKH-1 mice by apigenin, a plant flavonoid. Anticancer Res 1997, 17:85-91.

16. Van Dross $R, X u e Y$, Knudson A, Pelling JC: The chemopreventive bioflavonoid apigenin modulates signal transduction pathways in keratinocyte and colon carcinoma cell lines. J Nutr 2003, 133(Supp 1):3800-3804.

17. McVean M, Xiao H, Isobe K, Pelling JC: Increase in wild-type p53 stability and transactivational activity by the chemopreventive agent apigenin in keratinocytes. Carcinogenesis 2000, 21:633-639.

18. Wang W, Heideman L, Chung CS, Pelling JC, Koehler KJ, Birt DF: Cell-cycle arrest at G2/M and growth inhibition by apigenin in human colon carcinoma cell lines. Mol Carcinog 2000, 28:102-110.

19. Zheng P-W, Chiang L-C, Lin C-C: Apigenin induced apoptosis through p53-dependent pathway in human cervical carcinoma cells. Life Sci 2005, 76:1367-1379

20. Patel SD, Shukla S, Gupta S: Apigenin and cancer chemoprevention: Progress, potential and promise (Review). Int J Oncol 2007, 30:233-245.

21. $X u$ Y, Xin Y, Diao Y, Lu C, Fu J, Luo L, Yin Z: Synergistic effects of apigenin and paclitaxel on apoptosis of cancer cells. PLoS One 2011, 6:e29169.

22. Miyoshi N, Naniwa K, Yamada T, Osawa T, Nakamura Y: Dietary flavonoid apigenin is a potential inducer of intracellular oxidative stress: the role in the interruptive apoptotic signal. Arch Biochem Biophys 2007, 466:274-282.

23. Crespo I, García-Mediavilla MV, Almar M, González P, Tuñón MJ, SánchezCampos S, González-Gallego J: Differential effects of dietary flavonoids on reactive oxygen and nitrogen species generation and changes in antioxidant enzyme expression induced by proinflammatory cytokines in Chang Liver cells. Food Chem Toxicol 2008, 46:1555-1569.

24. Jeyabal PVS, Syed MB, Venkataraman M, Sambandham JK, Sakthisekaran D: Apigenin inhibits oxidative stress-induced macromolecular damage in $\mathrm{N}$ nitrosodiethylamine (NDEA)-induced hepatocellular carcinogenesis in Wistar albino rats. Mol Carcinog 2005, 44:11-20.

25. Chiang L-C, Ng LT, Lin I-C, Kuo P-L, Lin C-C: Anti-proliferative effect of apigenin and its apoptotic induction in human HepG2 cells. Cancer Lett 2006, 237:207-214

26. Khan TH, Sultana S: Apigenin induces apoptosis in HepG2 cells: possible role of TNF-a and IFN-a. Toxicology 2006, 217:206-212

27. Choi SI, CS J, Cho SY, YS L: Mechanisms of apoptosis induced by apigenin in HepG2 human hepatoma cells: Involvement of reactive oxygen species generated by NADPH oxidase. Arch Pharm Res 2007, 30:1328-1335

28. Valdameri G, Trombetta-Lima M, Worfel PR, Pires AR, Martinez GR, Noleto GR, Cadena SM, Sogayar MC, Winnischofer SM, Rocha ME: Involvement of catalase in the apoptotic mechanism induced by apigenin in HepG2 human hepatoma cells. Chem Biol Interact 2011, 193:180-189.

29. Shukla S, Gupta S: Apigenin: A promising molecule for cancer prevention. Pharm Res 2010, 27:962-978.

30. Wang IK, Lin-Shiau SY, Lin JK: Induction of apoptosis by apigenin and related flavonoids through cytochrome $\mathrm{c}$ release and activation of caspase-9 and caspase-3 in leukaemia HL-60 cells. Eur J Cancer 1999, 35:1517-1525.

31. Shukla S, Gupta S: Molecular mechanisms for apigenin-induced cell-cycle arrest and apoptosis of hormone refractory human prostate carcinoma DU145 cells. Mol Carcinog 2004, 39:114-126.

32. Shukla S, Gupta S: Apigenin-induced prostate cancer cell death is initiated by reactive oxygen species and p53 activation. Free Radic Biol Med 2008, 44:1833-1845.

33. Lu HF, Chie YS, Tan TW, Wu SH, Ma YS, Ip SW, Chung JG: Apigenin induces caspase-dependent apoptosis in human lung cancer A549 cells through Bax- and Bcl-2-triggered mitochondrial pathway. Int J Oncol 2010, 36:1477-1484.

34. Rithidech KN, Tungjai $M$, Whorton EB: Protective effect of apigenin on radiation-induced chromosomal damage in human lymphocytes. Mutat Res 2005, 585:96-104.

35. Khan TH, Jahangir T, Prasad L, Sarwat S: Inhibitory effect of apigenin on benzo(a) pyrene-mediated genotoxicity in Swiss albino mice. J Pharm Pharmacol 2006, 58:1655-1660

36. Siddique $\mathrm{YH}$, Ara G, Beg T, Afzal M: Anticlastogenic effect of apigenin in human lymphocytes treated with ethinylestradiol. Fitoterapia 2010, 81:590-594.

37. Snyder RD, Gillies PJ: Evaluation of the clastogenic, DNA intercalative, and topoisomerase II-interactive properties of bioflavonoids in Chinese hamster V79 cells. Environ Mol Mutagen 2002, 40:266-276.

38. Noel S, Kasinathan M, Rath SK: Evaluation of apigenin using in vitro cytochalasin blocked micronucleus assay. Toxicol in Vitro 2006, 20:1168-1172

39. Nafisi $S$, Hashemi M, Rajabi M, Tajmir-Riahi HA: DNA adducts with antioxidant flavonoids: morin, apigenin, and naringin. DNA Cell Biol 2008 27:433-442.

40. Kanakis CD, Nafisi S, Rajabi M, Shadaloi A, Tarantilis PA, Polissiou MG Bariyanga J, Tajmir-Riahi HA: Structural analysis of DNA and RNA interactions with antioxidant flavonoids. Spectroscopy 2009, 23:29-43.

41. Ross WE, Bradley MO: DNA double-strand breaks in mammalian cells after exposure to intercalating agents. Biochim Biophys Acta 1981 654:129-134.

42. Pommier $Y$, Schwartz RE, Zwelling LA, Kohn KW: Effects of DNA intercalating agents on topoisomerase II induced DNA strand cleavage in isolated mammalian cell nuclei. Biochemistry 1985, 24:6406-6410.

43. Albertini RJ, Anderson D, Douglas GK, Hagmar L, Hemminki K, Merlo F, Natarajan AT, Norppa H, Shuker DE, Tice R, Waters MD, Aitio A: IPCS guidelines for the monitoring of genotoxic effects of carcinogens in humans. Mutat Res 2000, 463:111-172.

44. Pandey M, Kaur P, Shukla S, Abbas A, Fu P, Gupta S: Plant flavone apigenin inhibits HDAC and remodels chromatin to induce growth arrest and apoptosis in human prostate cancer cells: in vitro and in vivo study. Mol Carcinog 2012, 51:952-962.

45. Thurn KT, Thomas S, Moore A, Munster PN: Rational therapeutic combinations with histone deacetylase inhibitors for the treatment of cancer. Future Oncol 2011, 7:263-283.

46. Morris SM, Casciano DA, Casto BC: Detection of carcinogens based in in vitro mammalian cytogenetic tests. In Handbook of carcinogen testing. 2nd edition. Edited by Milman HA, Weisburger EK. New Jersey: Noyes Publications; 1994:100-115

47. Solomon E, Bobrow M: Sister chromatid exchanges-a sensitive assay of agents damaging human chromosomes. Mutat Res 1975, 30:273-278.

48. Nakanishi Y, Schneider EL: In vivo sister-chromatid exchange: a sensitive measure of DNA damage. Mutat Res 1979, 60:329-337.

49. Das BC: Factors that influence formation of sister chromatid exchanges in human blood lymphocytes. Crit Rev Toxicol 1988, 19:43-86.

50. Marzano C, Bettio F, Baccichetti F, Trevisan A, Giovagnini L, Fregona D: Antitumor activity of a new platinum (II) complex with low nephrotoxicity and genotoxicity. Chem Biol Interact 2004, 148:37-48.

51. Lialiaris T, Lyratzopoulos E, Papachristou F, Simopoulou M, Mourelatos C, Nikolettos N: Supplementation of melatonin protects human lymphocytes in vitro from the genotoxic activity of melphalan. Mutagenesis 2008, 23:347-354.

52. Lialiaris TS, Kotsiou E, Pouliliou S, Kareli D, Makrinou H, Kouskoukis A Papachristou F, Koukourakis M: Cytoprotective activity of amifostine on cultured human lymphocytes exposed to irinotecan. Food Chem Toxicol 2009, 47:2445-2449. 
53. Lialiaris TS, Papachristou F, Mourelatos C, Simopoulou M: Antineoplastic and cytogenetic effects of chlorpromazine on human lymphocytes in vitro and on Ehrlich ascites tumor cells in vivo. Anti Cancer Drugs 2009, 20:746-751.

54. Turkez H, Tatar A, Hacimuftuoglu A, Ozdemir E: Boric acid as a protector against paclitaxel genotoxicity. Acta Biochim Pol 2010, 57:95-97.

55. Tofilon P, Basic I, Milas L: Prediction of in vivo tumour response to chemotherapeutic agents by the in vitro SCE assay. Cancer Res 1985 45:2025-2030

56. Denn DF, Kendall LA, Marton LJ, Tofilon P: Prediction of human tumour cell chemosensitivity using the SCE assay. Cancer Res 1986, 46:1599-1602.

57. Swierenga SHH, Heddle JA, Sigal EA, Gilman JPW, Brillinger RL, Douglas GR, Nestmann ER: Recommended protocols on a survey of current practice in genotoxicity testing laboratories, IV. Chromosome aberrations and sister chromatid exchanges in Chinese Hamster Ovary V79. Chinese Hamster lung and human lymphocyte cultures. Mutat Res 1991, 246:301-322.

58. Hagmar L, Bonassi S, Stromberg U, Brøgger A, Knudsen LE, Norppa H, Reuterwall C: European study group on cytogenetic biomarkers and health: chromosomal aberration in human lymphocytes predict human cancer: a report from the European study group on cytogenetic biomarkers and health (ESCH). Cancer Res 1998, 58:4117-4121.

59. El-Deiry WS: Regulation of p53 downstream genes. Semin Cancer Biol 1988, 8:345-357.

60. Kastan MB, Onyekwere O, Sidransky D, Vogelstein B, Craig RW: Participation of p53 protein in the cellular response to DNA damage. Cancer Res 1991, 51:6304-6311.

61. Clarke AR, Gledhill S, Hooper ML, Bird CC, Wyllie AH: p53 dependence of early apoptotic and proliferative responses within the mouse intestinal epithelium following gamma-irradiation. Oncogene 1994, 9:1767-1773.

62. Perry $P$, Wolff S: New Giemsa method for the differential staining of sister chromatids. Nature 1974, 251(5471):156-158

63. Lamberti L, Bigatti Ponzetto P, Ardito G: Cell kinetics and sister chromatid exchange frequency in human lymphocytes. Mutat Res 1983, 120:193-199.

64. Galloway SM, Wolff S: The relation between chemically induced sisterchromatid exchanges and chromatid breakage. Mutat Res 1979, 61:297-307.

65. Ikushima T: Role of sister chromatid exchanges in chromatid aberration formation. Nature 1977, 268:235-236.

66. Gebhart E: Sister chromatid exchange (SCE) and chromosome aberrations in mutagenicity testing. Hum Genet 1981, 58:235-254.

67. Latt SA: Sister chromatid exchanges, indices of human chromosome damage and repair: detection by fluorescence and induction by mitomycin C. Proc Natl Acad Sci USA 1974, 71:3162-3166.

68. Siddique $\mathrm{YH}$, Beg T, Afzal M: Antigenotoxic effect of apigenin against anticancerous drugs. Toxicol in Vitro 2008, 22:625-631

69. Begum N, Prasad NR, Kanimozhi G, Hasan AQ: Apigenin ameliorates gamma radiation-induced cytogenetic alterations in cultured human blood lymphocytes. Mutat Res 2012, 747:71-76.

70. Simon D, Aden DP, Knowle BB: Chromosomes of human hepatoma cell lines. Int J Cancer 1982, 30:27-33.

71. Zimonjic DB, Keck CL, Thorgeirsson SS, Popescu NC: Novel recurrent genetic imbalances in human hepatocellular carcinoma cell lines identified by comparative genomic hybridization. Hepatology 1999, 29:1208-1214.

72. Wong N, Lai P, Pang E, Leung TW-T, Lau JW-Y, Johnson PJ: A comprehensive karyotypic study on human hepatocellular carcinoma by spectral karyotyping. Hepatology 2000, 32:1060-1068.

73. Dronkert ML, Kanaar R: Repair of DNA interstrand cross-links. Mutat Res 2001, 486:217-247.

74. Helleday T: Pathways for mitotic homologous recombination in mammalian cells. Mutat Res 2003, 532:103-115.

75. Johnson DR, Jasin M: Sister chromatid gene conversion is a prominent double-strand break repair pathway in mammalian cells. EMBO J 2000 19:3398-3407

76. lijima K, Muranaka C, Kobayashi J, Sakamoto S, Komatsu K, Matsuura S, Kubota N, Tauchia H: NBS1 regulates a novel apoptotic pathway through Bax activation. DNA Repair 2008, 7:1705-1716.

77. Berkovich E, Monnat RJ, Kastan MB: Roles of ATM and NBS1 in chromatin structure modulation and DNA double-strand break repair. Nat Cell Biol 2007, 9:683-690
78. Bergamaschi D, Samuels Y, Jin B, Duraisingham S, Crook T, Lu X: ASPP1 and ASPP2: common activators of p53 family members. Mol Cell Biol 2004, 24:1341-1350

79. Rozan LM, El-Deiry WS: p53 downstream target genes and tumor suppression: a classical view in evolution. Cell Death Differ 2007, 14:3-9.

80. Strasser A, Harris AW, Jacks T, Cory S: DNA damage can induce apoptosis in proliferating lymphoid cells via p53-independent mechanisms inhibitable by Bcl-2. Cell 1994, 79:329-339.

81. Chao DT, Linette GP, Boise LH, White LS, Thompson CB, Korsmeyer SJ: Bcl$\mathrm{xL}$ and $\mathrm{BCl}-2$ repress a common pathway of cell death. J Exp Med 1995, 182:821-828.

82. Meikrantz W, Bergom MA, Memisoglu A, Samson L: O6-Alkylguanine DNA lesions trigger apoptosis. Carcinogenesis 1998, 19:369-372.

83. Zhang J, Reedy MC, Hannun YA, Obeid LM: Inhibition of caspases inhibits the release of apoptotic bodies: $\mathrm{BCl}-2$ inhibits the initiation of formation of apoptotic bodies in chemotherapeutic agent-induced apoptosis. J Cell Biol 1999, 145:99-108.

84. Ochs K, Kaina B: Apoptosis induced by DNA Damage $O$-Methylguanine is $\mathrm{BCl}-2$ and Caspase- $9 / 3$ regulated and Fas/Caspase- 8 independent. Cancer Res 2000, 60:5815-5824.

85. Friesen C, Herr I, Krammer PH, Debatin KM: Involvement of the CD95 (APO-1/Fas) receptor/ligand system in drug-induced apoptosis in leukemia cells. Nat Med 1996, 2:574-577.

86. Mueller M, Strand S, Hug H, Heinemann E-M, Walczak H, Hofmann WJ, Stremmel W, Krammer PH, Galle PR: Drug-induced apoptosis in hepatoma cells is mediated by the CD95 (APO-1/Fas) receptor/ligand system and involves activation of wild-type p53. J Clin Inves 1997, 99:403-413.

87. Leithäuser F, Dhein J, Mechtersheimer G, Koretz K, Brüderlein S, Henne C, Schmidt A, Debatin K-M, Krammer PH, Moller P: Constitutive and induced expression of APO-1, a new member of the nerve growth factor/tumor necrosis factor receptor superfamily, in normal and neoplastic cells. Lab Invest 1993, 69:415-429.

88. Cheng J, Zhou T, Liu C, Shapiro JP, Brauer MJ, Kiefer MC, Barr PJ, Mountz JD: Protection from Fas-mediated apoptosis by a soluble form of the Fas molecule. Science 1994, 263:1759-1762.

89. Cascino I, Fiucci G, Papoff G, Ruberti G: Three functional soluble forms of the human apoptosis-inducing Fas molecule are produced by alternative splicing. J Immunol 1995, 154:2706-2713.

90. Cascino I, Papoff G, Eramo A, Ruberti G: Soluble Fas/Apo-1 splicing variants and apoptosis. Front Biosci 1996, 1:d12-d18.

91. Filippov V, Schmidt EL, Filippova M, Duerksen-Hughes PJ: Splicing and splice factor SRp55 participate in the response to DNA damage by changing isoform ratios of target genes. Gene 2008, 420:34-41.

92. Izquierdo JM, Majós N, Bonnal S, Martínez C, Castelo R, Guigó R, Bilbao R, Valcárcel J: Regulation of Fas alternative splicing by antagonistic effects of TIA-1 and PTB on exon definition. Molec Cell 2005, 19:475-484.

93. Busa R, Geremia R, Sette C: Genotoxic stress causes the accumulation of the splicing regulator Sam68 in nuclear foci of transcriptionally active chromatin. Nucleic Acids Res 2010, 38:3005-3018.

doi:10.1186/1749-8546-8-9

Cite this article as: Papachristou et al:: Time course changes of anti- and pro-apoptotic proteins in apigenin-induced genotoxicity. Chinese Medicine 2013 8:9.

\section{Submit your next manuscript to BioMed Central and take full advantage of:}

- Convenient online submission

- Thorough peer review

- No space constraints or color figure charges

- Immediate publication on acceptance

- Inclusion in PubMed, CAS, Scopus and Google Scholar

- Research which is freely available for redistribution 